\title{
BIM Education Framework for Clients and Professionals of the Construction Industry
}

\author{
Ana Karina Silverio Rodriguez, University of Wolverhampton, Wolverhampton, UK \\ Subashini Suresh, University of Wolverhampton, Wolverhampton, UK \\ David Heesom, University of Wolverhampton, Wolverhampton, UK \\ Renukappa Suresh, University of Wolverhampton, Wolverhampton, UK
}

\begin{abstract}
Lack of qualified BIM professionals is a key BIM challenge that affects specific organisations and on a more macro scale, individual countries. A salient solution to this problem is the provision of better BIM education. This article represents the initial work into the implementation of BIM in the Dominican Republic, a country affected by different challenges in regard to BIM implementation, with a key issue surrounding the lack of BIM education. The aim of the article is the development of a conceptual BIM education framework which suggests strategies to be implemented in Academia and the industry for the delivery of BIM education to all the construction parties involved in a project, including the client. A literature review about BIM education and training and the revision of BIM education frameworks worldwide helped in its development. The framework is beneficial to this country as it is intended to be part of a toolkit, the final outcome of a $\mathrm{PhD}$ research on this country. However, it can be consulted by any country or organisation interested in developing BIM education strategies.
\end{abstract}

\section{KEYWORDS}

Academia, AEC Professionals, AEC Students, BIM Education Framework, BIM Education, Clients, Industry BIM Training

\section{INTRODUCTION}

As an innovative method for the design, construction, and operation of the built environment, BIM covers a wide variety of concepts, tools, and workflows that stakeholders in the industry need to learn and implement in their projects (Succar \& Sher, 2014). For a successful BIM implementation, it is essential that the members of the construction team have sufficient knowledge regarding those aspects (Suwal, Jäväjä, Rahman, \& Gonzalez, 2013). However, several studies have reported that there is shortage of qualified BIM professionals in the industry, which has become an important BIM barrier (Eadie, Browne, Odeyinka, McKeown, \& McNiff, 2013; Gardner, Hosseini, Rameezdeen, \& Chileshe, 2014; Lee \& Hollar, 2013; Wu \& Issa, 2013). In the same manner, training people or searching for people with BIM knowledge has represented a difficulty as to BIM implementation (Arayici et al., 2011).

BIM education is the solution to accelerate the BIM learning curve. Thus, companies can employ ready-made BIM professionals when students finish their studies (Wu \& Issa, 2013). Such education 
comprises different types of BIM learning: post-secondary education, industry workshops, online media and on-the-job training (AIA-CA, 2012).

The aim of this study is to develop a conceptual framework that contains the guidelines necessary for the development of BIM education strategies in Academia and the industry to "BIM educate" the construction parties involved in a project, including the client. For this purpose, the following research question was formulated: Which strategies should be implemented to "BIM educate" students of careers related to construction, current professionals of the field and clients for a successful implementation of BIM in construction projects? This research question targets the need to educate not only students who are not professionals yet but also current professionals of the construction industry with none BIM knowledge, as well as clients who are not commonly considered when referring to BIM education.

This conceptual framework was developed as part of the $\mathrm{PhD}$ research "Decision support toolkit to implement BIM in the Dominican Republic." The projected outcome of the study is a toolkit where the subject of BIM education is being considered as it plays an important role for this developing country where the implementation of BIM is in its infancy, and there is a notorious lack of BIM education.

In the following sections, a brief introduction to BIM education and training is presented. Furthermore, the research methodology provides a background of the $\mathrm{PhD}$ research, which adopted a qualitative approach. For the research, literature has been reviewed, and a preliminary data collection was conducted due to the lack of information about the topic in the country. Both, the literature and the preliminary data collection identified the need for a BIM education framework. The study then presents a review of the literature regarding BIM education and training, which focuses on the main BIM education providers: Academia and the industry. BIM education frameworks from different countries (Australia, New Zealand and the UK) are presented, analysed and compared. Findings of the preliminary study in regard to BIM education in the Dominican Republic are shown, and the development of the proposed conceptual BIM education framework is explained. Conclusions and further work are provided.

\section{BIM EDUCATION AND TRAINING}

Education is a process that implicates activities such as teaching, inducing, motivating, learning, examining, which is usually offered in schools and colleges (Oladosu, 2009). For a better understanding of the term, Jarvis (1995, in Garavan, 1997) lists its intrinsic characteristics: it must include a learning method, this method must not be an individual event, it is fundamentally humanistic, and learning must include understanding.

In regard to training, Peters (2010) includes it as one of the processes involved in getting educated. Oladosu (2009) defines it as the acquisition of skills in a particular field of specialisation which requires an exercising routine, continuous repetition and a definite end and objective. It is also important to mention that training is an activity commonly used in organisations, and can be even identified under the term "employee training" (Masadeh, 2012), which means obtaining on-the-job skills for a specific role.

Even though both terms have similarities and involve learning processes, there are differences among them. As presented in Table 1, such differences are regarding the scope, depth of the knowledge sought and the learning method applied for its acquisition.

After having a clear explanation of the terms education and training and their differences, a definition of BIM education was elaborated: BIM education is a continuous learning process that covers the knowledge required for individuals to be capable of being part and understand what a BIM process is. Such learning process needs to include the essential aspects of BIM implementation, the performance of the participants and the technical skills individuals need to acquire depending on the discipline they belong to and their role in the construction team.

BIM education and training is necessary not only within the whole construction industry but also must be directed to different levels: secondary level, undergraduate, practitioners' site and office staff, 
Table 1. Differences Between Education and Training (Oladosu, 2009; Masadeh, 2012)

\begin{tabular}{|l|l|}
\hline \multicolumn{1}{|c|}{ Education } & \multicolumn{1}{c|}{ Training } \\
\hline Broad scope & Limited field \\
\hline Knowledge development & Specific skills \\
\hline Theoretical method & Practical method \\
\hline Stricter background & Hands-on experience \\
\hline Mostly given in schools and higher education & Usually given on jobs \\
\hline
\end{tabular}

and even at the strategic level (Australian Construction Industry Forum \& Australasian Procurement and Construction Council, 2014)

As seen in Figure 1, there are numerous stakeholders implicated in the delivery of BIM education. Academia is the biggest domain among all of them since it covers educational institutions which provide education to a significant number of people. The industry is another important domain but what they mostly offer is training to their employees to develop the skills the company requires depending on their objectives and type of work. The remainder providers have a narrower scope. Software companies provide software training only. Local chapters of different associations offer varied types of training. From the UK, can be mentioned: BSI (British Standards Institution), BRE (Building Research Establishment), CIOB (Chartered Institute of Building), RICS (Royal Institution of Chartered Surveyor); Australia: CITB (Construction Industry Training Board). From the USA, AGC (Associated General Contractors) of America, etc. The BIM knowledge provided by BIM learners is the one they share with their colleagues, which can be acquired through professional experience, academic background or learned by themselves.

The variety and number of BIM education providers could infer that the need for BIM education is being addressed. However, the reports of the lack of BIM skilled personnel in the industry suggest that the way BIM education is being delivered and disseminated needs to be improved. Following the purpose and scope of this study, the investigation considered only the delivery of BIM education from the most important BIM education providers: Academia and the industry.

\section{RESEARCH METHODOLOGY}

Due to the scarcity of information about the construction industry in general and the presence of BIM in the Dominican Republic, was considered necessary the collection of primary data to investigate the topic. It was determined that the best way to collect data was through scrutinising the knowledge, points of views and experience of professionals in the Dominican construction industry. For that

Figure 1. BIM Education Providers (EWG, 2012; Rooney, 2017; CIC, 2013)




reason, a qualitative research approach was adopted since it is mostly implemented for identification, description, and conception of explanations (Crabtree \& Miller, 1999). Interviewing was the strategy implemented to collect such data as it helps researchers to explore people's views more in depth (Alshenqeeti, 2014), specifically through the conduction of semi-structured interviews.

The first data collection carried out was a preliminary study that took place in the Dominican Republic in January 2016. The study was conducted to explore the construction industry in the country and the levels of BIM awareness and implementation. 17 professionals from 12 construction organisations participated who were selected through purposive sampling, a widely used sampling strategy that gathers participants under some preselected criteria concerning a particular research question (Mack, Woodsong, MacQueen, Guest, \& Namey, 2005). The criteria to select the participants were that they needed to belong to the construction industry, be a permanent staff of construction organisations, and have knowledge of how the company works and develops their construction projects. Snowball sampling, a type of purposive sampling, was the strategy implemented to invite participants to the study. Professionals of the construction industry were contacted through the researcher's networking and they, in turn, referred other professionals to participate (Atkinson \& Flint, 2001).

The preliminary study fundamentally showed patterns of the way of work of Dominican construction organisations; BIM awareness levels; BIM implementation levels; interest in BIM implementation; and the challenges that affect these organisations in regard to BIM implementation, from where was identified the lack of BIM education in the country.

Figure 2. Research Process




On the other hand, as part of the literature review of the research, an investigation of BIM education was conducted. The literature on this topic suggested the development of a framework for the delivery of BIM education as a good initiative that could help to overcome the lack of BIM education in the country and be included in the proposed toolkit of the research. Consequently, a conceptual BIM education framework was developed from the literature review and the revision of existing BIM education frameworks of this nature worldwide. Figure 2 summarises the research process carried out.

\section{BIM IN TERTIARY AND HIGHER EDUCATION}

It is a general belief that the fundamental education needed to cover the lack of BIM skilled professionals is required for students of tertiary educational institutes (Hardin \& McCool, 2015; Miller, Sharma, Donald, \& Amor, 2013). Worldwide, academic institutions have begun teaching BIM implementation and have arranged courses to integrate BIM into current programs associated with the AEC industry (Sabongi, 2009; Wong, Wong, \& Nadeem, 2011). However, they have been criticised by scholars for their lack of plans and capabilities to insert and make use of BIM on current and future programs. In the same manner, numerous academic programs are experiencing difficulties in complying with the industry and students' expectations (Wu \& Issa, 2013).

\section{Challenges for Tertiary and Higher Education}

Research has shown numerous challenges affecting the insertion of BIM in Academia. A summary of them, classified by topic, is presented in Table 2 .

\section{Enhancing BIM for Tertiary and Higher Education}

In response to that, several researchers have proposed key actions to overcome some of the challenges affecting the insertion of BIM Academia and to improve the way BIM education is currently provided:

- Full programs should be revised and reformulated making emphasis in the changes arisen with BIM

- Nearly all disciplines need to modify their current programs to include BIM as one of the main subjects

- Insertion of national accreditation, if international academic accreditation cannot be introduced

- There should be a common framework that could be used to specify the requirements of which BIM topics could or should be integrated and how (Suwal et al., 2013)

- Incorporate collaboration requirements and BIM technical abilities within the BIM curricula to improve the capacity of graduates of different disciplines of the industry (Gardner et al., 2014)

- Important practical implementation of subjects and problems reported in real situations needs to be carried out after any training received (Kumar, 2015)

- The collaboration of the students in the process of creating a program and developing a curriculum (Wong et al., 2011)

\section{BIM TRAINING IN THE INDUSTRY}

BIM training within companies is a significant aspect of BIM education. Motivated by instant business benefit, numerous companies dedicated to designing, construction and operation provide the training required for their personnel to create and share data-rich models with their project partners. This type of training, which can be given either on the job or via registered training organisations, is mostly technical and aims to develop the necessary abilities to use the increasing number of tools and workflows that BIM offers. Nonetheless, another sort of training, such as the ones focused on 
Table 2. Challenges of BIM Education in Academia

\begin{tabular}{|c|c|}
\hline Topic & Challenges Identified \\
\hline $\begin{array}{l}\text { Curricula } \\
\text { development }\end{array}$ & $\begin{array}{l}\text { - Lack of space in the curriculum to introduce new courses to existing curriculum } \\
\text { - Objection to modify the curriculum to include BIM when there is the possibility that another } \\
\text { technology process could substitute BIM in a few years (Sabongi, 2009) } \\
\text { - Doubts if BIM should either be included in current curricula of AEC disciplines or be provided as } \\
\text { a particular subject on its own (Miller et al., 2013) } \\
\text { - Inquiries on how to adapt new subjects into an already full curriculum (Macdonald, 2012) } \\
\text { - How the insertion of BIM can affect the accreditation status of the curriculum (Kocaturk \& } \\
\text { Kiviniemi, 2013; Suwal et al., 2013) } \\
\text { - The restricted number of programs (required or optional) that students can take in the term they } \\
\text { are waiting to complete their courses (Sabongi, 2009) } \\
\text { - Programs focus mostly on software skills (Lee \& Hollar, 2013; Rooney, 2017) } \\
\text { - BIM treated as a design tool only (Wong et al., 2011) } \\
\text { - The insertion of BIM in simple, intensive and isolated courses (Lee \& Hollar, 2013; Magiera, } \\
\text { 2013) }\end{array}$ \\
\hline Cultural issues & $\begin{array}{l}\text { - Several academics still see BIM as a CAD software that students should learn by themselves in } \\
\text { their own time (Becerik-Gerber, Gerber, \& Ku, 2011) } \\
\text { - Resistance to change traditional teaching methods which have been implemented over many years } \\
\text { - Reluctance from people that have built their expertise to adopt a new concept where they are not } \\
\text { experienced or be trained again in a field they are not accustomed to } \\
\text { - Students are educated as traditionally: separated per departments and with minimum or no union } \\
\text { or collaboration among other discipline } \\
\text { - There is an incapacity to connect the traditional silos that are present in the architecture, } \\
\text { engineering and construction schools (Macdonald, 2012). } \\
\text { - Lack of support from faculty administrators and colleagues } \\
\text { - Lack of interest or reluctance from students to scrutinise the new technology (Sabongi, 2009) } \\
\text { - Doubts if creative artistic expression can be possible within a collaborative practice } \\
\text { - Uncertainties if professionals can preserve and defend their values in this innovative, cooperative } \\
\text { and democratic pluralism (Kocaturk \& Kiviniemi, 2013) }\end{array}$ \\
\hline $\begin{array}{l}\text { Issues related to } \\
\text { the and essence } \\
\text { and time of BIM } \\
\text { in the industry }\end{array}$ & $\begin{array}{l}\text { - Technologies typical of a BIM process tend to evolve very quickly, and academics that have been } \\
\text { kept out of the industry for some time may feel overwhelmed when attempting to keep updated } \\
\text { (Macdonald, 2012) } \\
\text { - Lack of knowledge and experience of academics (Becerik-Gerber et al., 2011; Gardner et al., 2014; } \\
\text { Kugbeadjor, Suresh, \& Renukappa, 2015; Rooney, 2017) } \\
\text { - How the current personnel will adapt to the new skills and understanding demanded by BIM } \\
\text { (Kocaturk \& Kiviniemi, 2013) } \\
\text { - BIM needs a determined knowledge of business practice and workflow which is hard to simulate } \\
\text { in a teaching course (Magiera, 2013) } \\
\text { - Shortage of books and other training materials (Gardner et al., 2014; Magiera, 2013; Sabongi, } \\
\text { 2009) } \\
\text { - Incertitude of which BIM platform (e.g.: Revit, Bentley, etc.) will become predominant (Sabongi, } \\
\text { 2009) } \\
\text { - The time that the implementation of BIM implies (Becerik-Gerber et al., 2011) }\end{array}$ \\
\hline High cost & $\begin{array}{l}\text { - BIM demands the use of state of the art IT equipment and high-priced software, and it can be } \\
\text { difficult for universities to get the correct IT environment (Hogle, 2013; Magiera, 2013) } \\
\text { - Similar to what happens in the industry, there is a mistrust among the professionals in Academia } \\
\text { and questions such as "who is responsible for" and "who will pay for" multidisciplinary courses can } \\
\text { arise (Macdonald, 2012). }\end{array}$ \\
\hline
\end{tabular}

the soft skills needed to direct cross-disciplinary teams and develop collaborative BIM projects (e.g., Team management skills, dispute resolution, meeting assistance) are given less frequently (AIA-CA, 2012). Computer Integrated Construction Research Program (2013) presents three key aspects that need to be considered when providing BIM training within companies (See Table 3):

Even though there are companies that prefer their own and unique in-house BIM training, some would suggest the insertion of BIM education and training into universities, particularly those with 
Table 3. Aspects Considered in the Provision of BIM Training in Companies (Computer Integrated Construction Research Program, 2013)

\begin{tabular}{|l|l|}
\hline Type of training & $\begin{array}{l}\text { - Internal } \\
\bullet \text { External }\end{array}$ \\
\hline Expertise levels & $\begin{array}{l}\text { • Management of the organisation: essential knowledge } \\
\bullet \text { Staff actively implementing BIM: broader knowledge }\end{array}$ \\
\hline Methods of training & $\begin{array}{l}\text { — Internal training created by a BIM champion } \\
\text { - Training from software providers and local chapters } \\
\bullet \text { Continuous training for the leading BIM staff }\end{array}$ \\
\hline
\end{tabular}

insufficient financial resources for training. In this manner, students will be BIM-skilled once they finish their careers and start working in the industry. Other companies would suggest that professional organisations offer non-technical BIM training for managerial positions (e.g. Project leaders, team managers); training that is mostly available through occasional BIM-related conferences and workshops (AIA-CA, 2012).

\section{Collaboration Among Academia and the Industry}

Academia is par excellence the provider of BIM education, and it is in the industry where the professionals get the chance to put their knowledge into practice and improve their skills. The alliance of both Academia and the industry has been highly suggested to increase the values and benefits from implementing BIM (Lee \& Hollar, 2013), cover the lack of BIM skilled professionals in the industry (AIA-CA, 2012; Hogle, 2013), and keep academics updated within the field (Macdonald \& Mills, 2011). Solutions and benefits with the partnership of Academia and the industry identified by several researchers are presented below:

- Faculty members who are responsible for teaching BIM-incorporated programs should keep in contact with the industry to redesign the contents of the programs showing industry tendencies and practices (Lee \& Hollar, 2013) and connect the gaps in theory and knowledge acquired from the experience of BIM professionals (Wu \& Issa, 2013)

- Opportunities from Academia for students to research on new technologies and processes, a challenging activity for the industry due to lack of time and resources (Hogle, 2013)

- Precise description of the specifications of the BIM oriented career path and the expectations of college BIM education learning outcomes from the industry

- Produce palpable incentives to get the attention and encourage students involved in the BIMdriven career path

- Implementation of different activities among both sectors to propel BIM education such as direct pedagogic contributions by BIM experts from industry, the share of knowledge with conferences or workshops among academics and professionals, and the preparation of formal BIM programs like co-ops and internships (Wu \& Issa, 2013). In the same manner, Hogle (2013) suggests planning site visits, case studies and the possibilities of visitor lecturing to help students to get involved in the learning process. Industry can point out the significance of material helping students to become better hires

- Implementation of practical learning methods in BIM curricula such as the creation and provision of modules sponsored by the industry

- Connecting academics with industry via knowledge transfer partnerships to produce training programs that provide exactly what the industry demands

- Creation of frameworks to direct the process of inserting BIM in existing curricula and creating new BIM curricula (Byrne, 2015) 
- Production of BIM teaching material by the Academia, industry experts, and BIM software developers to cover the lack of them. For that activity, it could be advantageous the creation of an online collaboration platform (Suwal et al., 2013)

\section{BIM Education and the Client}

To propel the best value of the whole BIM process is important that clients understand the basic principles of BIM. Thus, they are capable of demanding and issuing the correct information, at the right time and with the appropriate level of quality. By providing BIM education to clients, not only individual clients will get more benefits from the projects they are commissioning in the construction process and the long term but maybe, more significantly, they will turn into BIM supporters and help to spread its implementation (Sharp, 2015).

Client's knowledge on how to produce a detailed EIR (Employer's Information Requirement) and how to check the BEP (BIM Execution Plan) elaborated by the supply chain, according to what it has been established in the EIR is essential for an efficient BIM leadership on a project (Al Ahbabi \& Alshawi, 2015; Designing Buildings, 2016). Moreover, is important that clients know how to prepare an AIR (Asset Information Requirements) in detail. Thus, project delivery teams can give to the client the asset data he will require, avoiding the creation of too much information, which wastes time and fees. Clients need to be in a condition where they can ask the right questions and give the right information to get the most benefits of BIM after a project is completed (Sharp, 2015).

Certainly, clients need to understand what their role is and which things they need to demand and control in a BIM process. Following the definitions of education and training, it is more convenient that they receive BIM education as their need is to understand the process of BIM, not the acquisition of skills to perform any activity. However, it is not profitable for educational institutions to set up programs to educate those clients whose background may not be related to construction disciplines in some cases. Then, how can these be attained? A recommendation would be that this type of clients look for assessors and be instructed by the team they have employed. For this purpose, roles such as the BIM consultant/adviser have been created. A BIM consultant/adviser is designated in the first stages of a project to help clients in assessing long-term objectives for their business; delimiting the scope of BIM in their projects; using the information during the lifecycle of a project; and elaborating the EIR and revising the BEP (Designing Buildings, 2016).

\section{DRIVERS FOR INDUSTRY BIM KNOWLEDGE}

The involvement of the government is vital in the spread of the implementation of BIM and delivery of BIM education. Byrne (2015) recommends governments to give guidance in BIM education by implementing an organised method of collaboration through identifying and funding a proper and valued industry organisation to carry out a lead role for BIM; promoting BIM alliances among industry and educational institutions for research and the development of construction projects; and creating a BIM learning framework for academics, current practitioners, clients and new entrants.

Following are presented strategies that governments of various BIM leader countries have adopted to support and promote BIM education:

- The UK government created the BIM Task Group to prepare the government and the supply chain for the adoption of BIM level 2. This organisation has set opportunities to deliver resources, education, and training to the government and the industry (McGraw-Hill Construction, 2014). Moreover, it was created the BIM Academic Forum (BAF), a group of representatives from several UK universities that seeks to support the educational aspects of BIM. This group focused particularly on the creation of a BIM academic framework (Underwood, Khosrowshahi, Pittard, Greenwood, \& Platts, 2013), which will be explained in the next section. 
- The Scandinavia region (Finland, Norway, Denmark) has provided resources for education training and diffusion of case studies; and has worked for the enhancement of BIM education at university level.

- Singapore's Building Construction Authority (BCA) created a roadmap where education and motivational programs were set up to support the adoption of BIM in the AEC industry (McGrawHill Construction, 2014).

As per Sanchez, Kraatz, \& Hampson (2014), a government mandate would give the required context for BIM education providers (such as higher education and technical institutions) and professional organisations to cooperate in the creation of new courses to upskill the professionals of the construction industry who are getting ready for the mandate. Nevertheless, there are other means where BIM education can be encouraged and promoted. A good example identified in this study is Australia, where none step has been taken by the Commonwealth Government to create a national mandate for the implementation of BIM (Sanchez et al., 2014). However, various initiatives to support BIM education have arisen in this country: Creation of working groups, development of frameworks and alliances of working groups with universities (Rooney, 2017).

\section{BIM EDUCATION FRAMEWORKS}

In the literature review, BIM education frameworks to be implemented in Academia and the industry were sought and revised for the development of the proposed conceptual framework. Frameworks for Academia that were elaborated for specific modules/courses were not contemplated as they were not in line with the aim of the proposed framework. There were only considered frameworks that were elaborated to guide the delivery of BIM education in general, not for specific courses. In regard to BIM education frameworks for the industry, there were not found as many as the ones for Academia. However, all of them were considered for the analysis.

The BIM education frameworks analysed are from Australia, UK, and New Zealand. A summary of each framework is presented in Table 4. They were classified under the following criteria: those to be implemented in Academia, those to be implemented in the industry and those that encompass both domains.

\section{Academic Education Frameworks}

The necessity of a framework to assist the implementation of collaborative design and BIM education by Architecture, Engineering, and Construction (AEC) institutions has been stated before (Macdonald \& Granroth, 2013; Macdonald, 2012; Macdonald \& Mills, 2011). Following is presented a brief background and explanation of the frameworks for Academia considered in this study:

\section{IMAC Framework}

The Australian Office of Learning and Teaching (OLT) funded a project called Code BIM for the elaboration of a framework that could assist AEC academics in the insertion of collaborative programs using BIM tools and procedures (Macdonald \& Granroth, 2013). The framework encompasses two components: a benchmarking tool and an independent guide to implementation. It is divided into four stages, which describe different levels of accomplishment (See Table 4) and does not command in which academic year each stage should be inserted.

This framework is basic, yet shows a good strategy of how BIM education should be provided in Academia: First, an introduction of BIM in the discipline the students belong to is given; then they acquire technical skills, per their discipline, and start getting knowledge about BIM principles. After that, they develop the capacity to solve problems in their disciplines and can work collaboratively with people of other disciplines on a BIM project. 
Table 4. Breakdown of the Frameworks Found in the Literature

\begin{tabular}{|c|c|c|c|}
\hline & Sections & Points covered & Actors involved \\
\hline \multicolumn{4}{|c|}{ Frameworks for BIM education in Academia } \\
\hline $\begin{array}{l}\text { IMAC framework } \\
\text { (Australia) } \\
\text { Code BIM Project: } \\
\text { Australian Office of } \\
\text { Learning and Teaching } \\
\text { (OLT) along with } \\
\text { the University of } \\
\text { Technology Sydney, } \\
\text { University of South } \\
\text { Australia and University } \\
\text { of Newcastle } \\
\text { (MacDonald, 2012; } \\
\text { Macdonald \& Granroth, } \\
\text { 2013; Macdonald \& } \\
\text { Mills, 2011) }\end{array}$ & $\begin{array}{l}\text { Stages of the framework: } \\
\text { - Illustration } \\
\text { - Manipulation } \\
\text { - Application } \\
\text { - Collaboration }\end{array}$ & $\begin{array}{l}\text { Provides a benchmarking } \\
\text { tool and a guide to assist } \\
\text { academics in the insertion of } \\
\text { collaborative design education } \\
\text { and BIM in AEC curricula }\end{array}$ & $\begin{array}{l}\text { - Providers: } \\
\text { - Academia } \\
\text { - Beneficiated: } \\
\text { - Students (levels not specified) }\end{array}$ \\
\hline $\begin{array}{l}\text { New Zealand's } \\
\text { national draft } \\
\text { framework: } \\
\text { The University of } \\
\text { Auckland (Miller et al., } \\
\text { 2013) }\end{array}$ & $\begin{array}{l}\text { Includes the three types } \\
\text { of education that the } \\
\text { study considers necessary } \\
\text { in a BIM educational } \\
\text { framework: } \\
\text { - Vocational training and } \\
\text { continuing professional } \\
\text { development } \\
\text { - Degree Programmes } \\
\text { (Undergraduate and } \\
\text { Masters) } \\
\text { - Research (including } \\
\text { PhDs) } \\
\text { The requirements of } \\
\text { each type of education } \\
\text { are explained in three } \\
\text { domains encompassed } \\
\text { in the implementation of } \\
\text { BIM: } \\
\text { - Architecture, } \\
\text { Engineering, and } \\
\text { Construction } \\
\text { - Software and } \\
\text { Technologies } \\
\text { - Business, Enterprise, } \\
\text { and Management }\end{array}$ & $\begin{array}{l}\text { - Specifications of learning } \\
\text { outcomes demanded by } \\
\text { Vocational Training/ } \\
\text { Continuing Professional } \\
\text { Development (CPD) in the } \\
\text { three domains } \\
\text { - Proposes the insertion of } \\
\text { BIM in existing bachelor's } \\
\text { degree's curricula } \\
\text { - Proposes the creation of } \\
\text { Integrated BIM masters } \\
\text { - Considers carrying out } \\
\text { research in further areas than } \\
\text { the ones presented in the } \\
\text { framework }\end{array}$ & $\begin{array}{l}\text { - Providers: } \\
\text { - Academia } \\
\text { - CPD providers } \\
\text { - Beneficiated: } \\
\text { - Current AEC practitioners } \\
\text { - Undergraduate, masters, and } \\
\text { research students }\end{array}$ \\
\hline \multicolumn{4}{|c|}{ Frameworks and roadmaps for BIM education in the industry } \\
\hline $\begin{array}{l}\text { Kumar's framework } \\
\text { (UK) } \\
\text { (Kumar, 2015) }\end{array}$ & $\begin{array}{l}\text { Elements } \\
\text { - BIM champion } \\
\text { - Perception of challenges } \\
\text { (internal and external) } \\
\text { - Training program } \\
\end{array}$ & $\begin{array}{l}\text { - BIM strategy suggested } \\
\text { for organisations to meet the } \\
\text { levels of expertise required for } \\
\text { the implementation of BIM. }\end{array}$ & $\begin{array}{l}\text { - Providers: } \\
\text { - Industry } \\
\text { - Beneficiated: } \\
\text { - Current AEC practitioners }\end{array}$ \\
\hline $\begin{array}{l}\text { Kumar's roadmap } \\
\text { (UK) } \\
\text { (Kumar, 2015) }\end{array}$ & $\begin{array}{l}\text { - Knowledge diffusion } \\
\text { of government's BIM } \\
\text { strategies } \\
\text { - Information diffusion of } \\
\text { documents published by } \\
\text { the BIM Task Group } \\
\text { - Evaluation and analysis } \\
\text { of organisational training } \\
\text { requirements } \\
\text { - Elaboration of a } \\
\text { compendious training } \\
\text { strategy } \\
\text { - Revision of the training } \\
\text { and policy strategy } \\
\text { through feedback and } \\
\text { audit of earlier phases. }\end{array}$ & $\begin{array}{l}\text { - Diffusion of governments } \\
\text { BIM strategies in the } \\
\text { organisation; } \\
\text { - Elaboration of a BIM } \\
\text { training strategy }\end{array}$ & $\begin{array}{l}\text { - Providers: } \\
\text { - Industry } \\
\text { - BIM training providers } \\
\text { - Beneficiated: } \\
\text { - Current AEC practitioners }\end{array}$ \\
\hline
\end{tabular}




\begin{tabular}{|c|c|c|c|}
\hline & Sections & Points covered & Actors involved \\
\hline $\begin{array}{l}\text { Collaborative BIM } \\
\text { education framework } \\
\text { from the BIM } \\
\text { Education Working } \\
\text { Group (EWG) } \\
\text { (Australia) } \\
\text { (AIA-CA, 2012; Succar } \\
\text { \& Sher, 2014) }\end{array}$ & $\begin{array}{l}\text { Components: } \\
\text { - A: Identifying BIM } \\
\text { Competencies } \\
\text { - B: Classifying BIM } \\
\text { Competencies } \\
\text { - C: Arranging } \\
\text { competencies and } \\
\text { designing BIM learning } \\
\text { modules } \\
\text { - D: An industry } \\
\text { framework for } \\
\text { professional development } \\
\text { - E: An academic } \\
\text { framework for BIM } \\
\text { Education } \\
\text { - F: The BIM Institute }\end{array}$ & $\begin{array}{l}\text { - Identification of BIM } \\
\text { competencies } \\
\text { - Creation of an online BIM } \\
\text { learning hub } \\
\text { - Creation of BIM learning } \\
\text { modules } \\
\text { - Creation of BIM learning } \\
\text { materials } \\
\text { - Creation of an Industry } \\
\text { framework for professional } \\
\text { development in the industry } \\
\text { - Expansion of existing and } \\
\text { creation of innovative CPD } \\
\text { programmes } \\
\text { - Creation of an Academic } \\
\text { framework } \\
\text { - Expansion of existing } \\
\text { and creation accredited } \\
\text { programmes } \\
\text { - Creation of a BIM institute }\end{array}$ & $\begin{array}{l}\text { - Providers: } \\
\text { - Academia } \\
\text { - Industry } \\
\text { - Other BIM education providers } \\
\text { - Beneficiated: } \\
\text { - Students (levels not specified) } \\
\text { - Current AEC practitioners }\end{array}$ \\
\hline $\begin{array}{l}\text { Learning Outcomes } \\
\text { framework } \\
\text { (UK) } \\
\text { BIM TASK GROUP } \\
\text { and BAF } \\
\text { (BIM Level 2, 2016; } \\
\text { BIM Task Group, 2012; } \\
\text { Underwood et al., 2013; } \\
\text { Underwood et al., 2015) }\end{array}$ & $\begin{array}{l}\text { Categories of the initial } \\
\text { framework: } \\
\text { - Strategic; } \\
\text { - Management; } \\
\text { - Technical. } \\
\text { Categories of the final } \\
\text { version: } \\
\text { - Understand the essence } \\
\text { BIM, BIM Level } 2 \\
\text { requirements established } \\
\text { and its relation with the } \\
\text { Government Construction } \\
\text { Strategy 2025 } \\
\text { - Understand the } \\
\text { implications and value of } \\
\text { BIM in the organisation } \\
\text { - Understand the } \\
\text { requirements for } \\
\text { information management } \\
\text { and exchange described } \\
\text { in the } 1192 \text { suite of } \\
\text { standards PAS55 / ISO } \\
\text { 55000. }\end{array}$ & $\begin{array}{l}\text { Provides the learning } \\
\text { outcomes (LOF) needed } \\
\text { to implement BIM level } 2 \\
\text { successfully. It can be applied } \\
\text { in both the industry and } \\
\text { Academia. } \\
\text { For the implementation in } \\
\text { Academia, the LOFs are } \\
\text { specified for undergraduate } \\
\text { levels }(4,5 \text { and } 6 \text { ) and post- } \\
\text { graduate level (7). }\end{array}$ & $\begin{array}{l}\text { - Providers: } \\
\text { - Academia } \\
\text { - Industry } \\
\text { - Beneficiated: } \\
\text { - Current AEC practitioners } \\
\text { - Undergraduate and post- } \\
\text { graduate students }\end{array}$ \\
\hline
\end{tabular}

\section{Application}

Macdonald (2012) states that the benchmarking tool of this framework has been implemented at the three universities part of the Code BIM to benchmark existing courses project and outline goals for future curriculum improvements. Table 5 presents two cases where the framework was implemented in two of these universities:

\section{New Zealand's National Draft Framework}

The University of Auckland in New Zealand elaborated a draft educational framework to start discussions and create a general agreement in the academic community about a national a BIM educational framework. For the development of the framework, knowledge domains were classified and mapped to the NZQF (New Zealand Qualifications Framework) (See Table 4). The study considered it was too early to determine the content of the programmes, however a set of goals and intended learning outcomes was outlined to encourage debate. The study suggests further research for the development of the learning outcomes proposed. Such research must consider the specific needs of SME's (Miller et al., 2013). 
Table 5. Implementation of IMAC Framework (Rooney, 2017; Tran, Mills, Morris, \& Phillips, 2012)

\begin{tabular}{|l|l|}
\hline University of South Australia (UniSA) & University of Technology Sydney: UTS \\
\hline Purpose: Benchmarking of two courses & Purpose: Development of a class \\
\hline $\begin{array}{l}\text { Construction in the Workshop course and } \\
\text { Construction on site course: The benchmarking aimed } \\
\text { to identify if the courses were useful in developing } \\
\text { collaborative design competencies in the students. } \\
\begin{array}{l}\text { Afterwards, it was recommended to make the classes more } \\
\text { collaborative and the insertion of BIM tools. }\end{array}\end{array}$ & $\begin{array}{l}\text { IPD studio class: Multi-disciplinary students had to work } \\
\text { during one semester on a project implementing BIM tools } \\
\text { and processes and learning how to work collaboratively } \\
\text { in a team and the information required from their partner } \\
\text { disciplines. }\end{array}$ \\
\hline
\end{tabular}

\section{Industry Frameworks}

\section{Kumar's Framework}

As noted by Kumar (2015), is important that an organisation elaborates a BIM strategy to assure that it meets the necessary levels of expertise to implement BIM processes and technologies on their projects. Through three elements (See Table 4), this framework presents three steps that an organisation needs to take to be ready to develop training and policy strategies. The first action suggested is the designation of a BIM champion, who needs to be a passionate person with vast knowledge of BIM. Secondly, the organisation needs to assess the challenges that affect the implementation of BIM. This assessment needs to consider internal (i.e. cultural resistance, lack of BIM skilled personnel) and external challenges (i.e. high competition, lack of BIM qualified professionals locally). After that, the framework states that the organisation is ready to create a training and policy strategy.

\section{Kumar's Roadmap to be Implemented in the UK Construction Industry}

Along with the framework, Kumar (2015) proposes a roadmap organisations can apply once they are ready to develop a BIM training. The roadmap considers 5 phases (See Table 4). The first two focus on the diffusion of the UK BIM strategy within the organisation. Then, an evaluation of the training that the organisation needs is suggested. Once the training needs are identified, a training and policy strategy is elaborated, which consists of the following:

1. The classification of the training according to the LOF (Learning Outcomes Framework), which will be explained in the next framework

2. Identification of the staff and their mapping into the different classifications

3. Identification of staff's training needs that are relevant to the organisation

4. Programming the training courses

5. Execution

6. Feedback and audit

In the end, the training strategy and regulations should be revised considering feedback and audits of earlier phases.

\section{Education Frameworks for Academia and Industry}

\section{Collaborative BIM Education Framework from the BIM Education Working Group (EWG)}

Since the beginning, this framework suggests working collaboratively. The framework has six components (See Table 4). In the first three, it proposes how the BIM learning modules can be designed, a process that starts with the identification of BIM competencies. Such competencies need to be classified and organised to create learning modules which, in turn, need to be examined and classified as well. For that, and for the elaboration of BIM learning materials, is proposed the 
creation of an online learning hub where BIM education providers and other stakeholders can work collaboratively. The following two components recommend the creation of frameworks. One of them is an industry framework for industry associations to work collaboratively in the spread and creation of collaborative training for BIM, in the form of CPD programs, for example. The other one is an academic framework for educational institutions to work together in the spread and creation of new accredited programs. The last component consists in the creation of a National BIM Institute to promote BIM learning and support the implementation of the Collaborative framework.

\section{Learning Outcomes Framework (LOF)}

The BIM Task group published a preliminary BIM Learning Outcomes Framework (LOF) to give information and orientate Academia, organisations, training providers and private educators in elaborating and delivering training programs to professionals in the industry. The framework was initially outlined to focus independently on three functions: Strategic, Management, and Technical (BIM Task Group, 2012). Subsequently, the BIM Task Group in collaboration with the BIM Academic Forum (BAF), developed a 2015 version of the LOF. This version contains the BIM level 2 support documents and covers academic and industry feedback on its implementation, presentation format, organisation and content (Underwood et al., 2015). The LOF does not give training or programs content. It presents the topics that should be taken into consideration for a standard BIM level 2 execution (BIM Level 2, 2016).

\section{BAF LOF}

In 2012, BAF carried out a workshop aiming to show to a bigger audience their preliminary work of the BIM academic framework and the initial outcomes of earlier working group sessions and to assist in the further improvement of the framework and the related learning outcomes. In the workshop were defined the learning outcomes (BAF LOF) demanded in undergraduate degrees (level 4, 5 and 6) and postgraduate degrees (level 7). They consider the following disciplines: architecture; architectural technician/technologist; building services engineering; civil engineering; construction management and construction project/design management; quantity surveying; and BIM Masters. The learning outcomes are divided into three categories: Knowledge and understanding; practical skills and transferable skills (Underwood et al., 2013). The term BAF ILO, which means Intended Learning Outcomes, is presented by (Underwood et al., 2015) and refers to the three categories previously mentioned.

\section{Application}

Adamu (2016) shows a 3-year plan elaborated in Loughborough University to BIM upgrade 26 priority modules in undergraduate and post-graduate degrees. To embed BIM into the priority modules, the BAF ILOs were mapped into the ILOs of the existing modules. It is important to point out that the modules were also mapped into the BIM Maturity Diagram. The BAF ILOs guided the creation of new BIM-specific or BIM-relevant modules:

- $\quad$ BSc: CVB042 3D BIM Auditing and Coordination.

- BSc and MSc: CVC045 Collaborative. BIM Design Project.

\section{Critical Comparison of BIM Education Frameworks}

Graphically, the IMAC is simple. It is peculiar regarding the process of getting taught, taking into consideration learning principles and ideal activities for acquiring knowledge. It does not include learning outcomes. Instead, it shows the stages students need to go through in a BIM learning process. Moreover, its implementation is opened as it does not specify the year or type of education in which each stage should be implemented. 
The New Zealand's national draft framework is the framework that includes the most varied kinds of education: bachelor's and master's degrees, research and VT/CPD. However, it is vague in a certain way. It is more explanatory in the VT/CPD type of education rather than in the remainder forms of education. In the elaboration of the framework were proposed goals and learning outcomes on different types of education, however, they were not included in the framework. If further research is undertaken, as specified in the study, the framework will be probably more complete with the inclusion of those learning outcomes.

Alike the IMAC, Kumar's framework is very simple graphically but is also simple in the content. The framework serves more as a preparation tool. It helps organisations to assess themselves before getting into the development of a training strategy. The roadmap he proposes along with the framework describes key points of how this strategy can be developed. It suggests the use of the LOF framework to classify the training to be provided in the organisation.

The EWG collaborative BIM education framework is the only framework that proposes the collaboration of Academia and the industry for the propagation of BIM education. Similar to the New Zealand's framework, this framework is a draft. It is the broadest framework as it proposes BIM education strategies to be implemented at a national level and suggest the development of two frameworks, one for Academia and one for the industry. These two frameworks do not contain any BIM learning outcomes nor describe the process of how BIM education can be provided in these two domains. They just state how important the collaboration in Academia and the industry is for the enhancement and development of new courses in both fields.

The LOF is the only framework studied which is based on a national BIM mandate. That makes the implementation of the framework very efficient. If it is followed and mapped correctly by any academic institution or construction company, BIM learners are more likely to be on the right path of getting the education they need to meet the requirements to implement BIM level 2, which is the goal of the UK BIM strategy thus far. The LOF is very specific as to the requirements of BIM Level 2. However, it was noted that when implemented in Academia (BAF LOF), the learning outcomes appear to be more general in regard to BIM level 2. Moreover, it was observed that the framework demands more learning outcomes from master's than from undergraduate's degrees.

Regarding their practical application, there were only found examples of the IMAC and the BAF LOF. Two examples where the IMAC was used were identified. One of them used it as a benchmarking tool for the improvement of two courses (UniSA) and the other one for the creation of a new course (UTS). The usage of the framework as a benchmarking tool could be seen in the study of Tran et al. (2012), where the mapping process of the two courses against the framework is explained in detail. However, the usage of the framework for the creation of new courses could not be explored very well as Rooney (2017) does not specify how this process was done in the IPD Studio Class at UTS, and there were not found any other sources containing this information. On the other hand, the example of implementation of the BAF LOF in Loughborough University showed how beneficial learning outcomes are for the creation and content guidance of BIM programs. The three new courses were developed in compliance with the BIM Level 2 requirements from the UK and all the aspects to be taught to the students were specified.

\section{PRELIMINARY STUDY OF BIM IN THE DOMINICAN REPUBLIC}

As stated before, the proposed conceptual framework of this study is part of the $\mathrm{PhD}$ research "Decision support toolkit to implement BIM in the Dominican Republic", where a preliminary study has already been conducted to collect primary data in the country. In brief, the results on BIM showed high levels of BIM awareness but low levels of BIM understanding and implementation. It was identified only one project that was developed with BIM, but not at its fullest. Thus far, the Dominican government has not expressed any interest in implementing BIM. Instead, the adoption of BIM is timidly driven by the private sector. Besides those findings, the pilot study also showed further steps that need to 
be considered for the main data collection. One of them was to investigate about BIM education in the country. Modest manifestations and attempts of delivery of BIM education were mentioned by the interviewees who also identified the lack of BIM education as a challenge for the implementation of BIM in the country:

- “INV-007-PRI-ENG: I don't think that here there is an institution that teaches you about BIM as a whole. They can mention software, and that's it, but there is not a place where you can go to study BIM."

The evidence of BIM education mentioned by the interviewees was mainly software based. Various interviewees stated that there are several centres where people can be trained in BIM software. Even the companies that reported to be in the path of implementing BIM within their practices have only provided software training to their employees:

- "INTERVIEWER: So, has Revit been the only training related to BIM that the company has offered to their employees?

- INV-011-PRI-ARCH: Yes. Revit and Navisworks."

On the other hand, it was found that there are possibilities of inserting BIM in Academia. One interviewee, who also works as a professor at a famous university in the country, stated that the Director of this university wants to insert BIM in the curricula of Civil Engineering careers:

- "INV-006-PUB-ENG: In fact, BIM... the idea of the Director of the University where I am professor is to teach BIM in all the Civil Engineering careers because in Civil Engineering you have a lot of projects of different disciplines..."

The findings of the preliminary study on BIM education, especially the interest of one representative of a university to include BIM in existing curricula, suggests that the topic of BIM education is an essential aspect to be considered in the toolkit. The biggest problem found in the current BIM education provided in the country is the focus on software skills, which is not the only knowledge required to implement BIM.

Undoubtedly, the country needs guidance on how to develop and deliver the BIM education required for a successful implementation of BIM within the industry. The proposed BIM education framework is a first attempt to provide such guidance for the country. Moreover, further data collection has been planned to confirm the information related to BIM education provided by the interviewees and collect more primary data about the subject.

\section{DEVELOPMENT OF THE PROPOSED BIM EDUCATION FRAMEWORK}

The proposed conceptual framework is directed to BIM educate students, current practitioners, and clients. The framework does not follow any governmental BIM mandate; it just focuses on the aspects needed for the development of a BIM education plan in Academia and the industry, the most important domains where BIM learners can seek BIM education.

In the development process, the framework was first divided into two sections: one for Academia and one for the industry (See Table 6). The literature suggests the partnership of both domains for the delivery of BIM education, therefore was considered necessary to state when the collaboration of both domains is needed. The section of Academia covers higher education institutions, and the industry includes the preparation of professionals in construction organisations. The education for clients was embedded into the industry section. Secondly, a series of actions to enhance the delivery 
of BIM education suggested in the literature and identified in the analysed frameworks was listed. The activities were classified by the domain they need to be implemented, either Academia or the industry. In agreement with the characteristics of the actions listed, each area was divided into three sections, which represent the steps that both domains need to take in a BIM education plan: Strategy, Implementation, and Revision. After having both areas divided into three stages, the actions were organised and listed in the order they should be executed.

As identified by the literature, BIM education in Academia is the most required BIM education for the preparation of BIM skilled professionals. Therefore, the section of the framework dedicated to Academia appears to be more complex than the one for the industry. In the framework, can be seen that Academia also requires a wider collaboration of different participants. For this collaboration, a good solution is suggested in the EWG framework with the creation of an online platform where all these actors can interact, learn from each other and contribute with ideas, producing a win-win situation.

In both sections of the framework, leadership is required for the development of the strategies, which is the first stage. In Academia, the collaboration with the industry is needed from the establishment of this leadership. The best option for this purpose is to gather academics and people from the industry that are interested in the improvement of BIM education and create groups or associations. It is ideal that these groups get support from the government, so they have more influence in Academia and the industry. On the other hand, in the industry, the process is simpler. The strategy can be established by a BIM champion, who is designated by the company as suggested by Kumar (2015).

The actions in the implementation stage are very different in both domains. In Academia is mostly based on: the preparation of the educators; the creation of BIM programs and the insertion of BIM in existing programs; the elaboration of BIM teaching material; the encouragement for students to develop more their skills through the diffusion of other types of BIM education (workshops, conferences, seminars, etc.); and the creation/support of post-graduate programs (masters, research, etc.). For the preparation of the BIM programs, it is important that the developers include all the aspects needed for professionals to manage a BIM process in a project. As stated by Maghiar (2016), BIM programs should teach students the following aspects for them to be able to implement BIM successfully in real-world scenarios: workflow of construction process; how technology is applied in this workflow; roles and responsibilities of the construction parties: designers, owners, construction managers; cooperation and integration of people in the construction delivery; and interoperability and capacity of the software implemented. It is also important for students to understand how the collaboration among disciplines is performed on a BIM project. For that, it is first advised to develop the individual skills of the students and then get them involved in collaborative activities where other skilled students can be part of, as proposed in the IMAC framework. These activities can be created by sharing modules where students of different disciplines work on projects together. This task is more complex in programs such as master's degrees which are less populated, and the diversity of professions is not constant.

In the industry, the implementation stage consists in the provision of education and training required by the staff depending on their role in the company. Training can be provided by the company if they have the qualified staff to do so. They can also receive BIM education by getting enrolled in BIM programs from Academia or training from other BIM providers. In regards to clients, the industry should encourage them to be part of the BIM process as much as they can, even when they do not professionally belong to the construction sector. As the education required for a client does not need to be as deep as the one the developers of the project need, it was only specified the designation of a BIM consultant to be their adviser. However, it was indicated that they could get involved in educational activities such as seminars and short programs if they are interested or if it is considered necessary.

After the implementation of the BIM education plan, the revision stage is highly needed for both domains to confirm if the plan implemented was successful or not. For this stage, feedback from students is essential in Academia. With their collaboration, it can be identified if all the material 
Table 6. Proposed Framework

\begin{tabular}{|c|c|c|c|c|}
\hline \multicolumn{5}{|c|}{ Academia } \\
\hline \multirow[t]{2}{*}{ Strategy stage } & \multicolumn{3}{|c|}{ Implementation stage } & \multirow[t]{2}{*}{ Revision stage } \\
\hline & & Actions & Participants involved & \\
\hline \multirow{6}{*}{$\begin{array}{l}\text { - Creation of groups } \\
\text { with members from } \\
\text { Academia and the } \\
\text { industry to lead the } \\
\text { strategy } \\
\text { - Identification of the } \\
\text { BIM abilities needed } \\
\text { per discipline from the } \\
\text { educators } \\
\text { - Identification of the } \\
\text { BIM skills per discipline } \\
\text { required from the } \\
\text { students } \\
\text { - Categorisation of } \\
\text { these abilities by } \\
\text { themes, according to the } \\
\text { knowledge disciplines of } \\
\text { the construction industry }\end{array}$} & \multicolumn{2}{|c|}{$\begin{array}{l}\text { Provision of education and training required for } \\
\text { the educators. }\end{array}$} & $\begin{array}{l}\text { - Academics } \\
\text { - BIM education providers } \\
\text { - Industry }\end{array}$ & \multirow{6}{*}{$\begin{array}{l}\text { Assessment of the programs } \\
\text { created by getting feedback } \\
\text { from: } \\
\text { - BIM learners: to express } \\
\text { their opinion about program } \\
\text { and learning outcomes } \\
\text { - Academics: by analysing the } \\
\text { progress and performance of } \\
\text { the students } \\
\text { - Industry: by the evaluation } \\
\text { of the BIM learners } \\
\text { skills when practical } \\
\text { implementation activities are } \\
\text { programmed }\end{array}$} \\
\hline & \multicolumn{2}{|c|}{$\begin{array}{l}\text { Elaboration of the learning modules: } \\
\text { - To be embedded in current programs } \\
\text { - For the creation of new programs }\end{array}$} & $\begin{array}{l}\text { - Academics } \\
\text { - Industry } \\
\text { - BIM education providers } \\
\text { - BIM learners } \\
\text { - Researchers } \\
\text { - Government (as support) }\end{array}$ & \\
\hline & \multicolumn{2}{|c|}{$\begin{array}{l}\text { Creation of BIM learning materials for new } \\
\text { modules inserted and programs modified. }\end{array}$} & $\begin{array}{l}\text { - Academics } \\
\text { - Industry } \\
\text { - BIM providers } \\
\text { - BIM learners } \\
\text { - Researchers }\end{array}$ & \\
\hline & \multicolumn{2}{|c|}{$\begin{array}{l}\text { Practical implementation of the } \\
\text { knowledge acquired: } \\
\text { - Knowledge transfer partnerships; } \\
\text { - Internships; } \\
\text { - Co-ops. }\end{array}$} & $\begin{array}{l}\text { - Academics: for planning; } \\
\text { - Industry: to provide } \\
\text { opportunities to the BIM } \\
\text { learners; } \\
\text { - Government: to promote this } \\
\text { practice in BIM education. }\end{array}$ & \\
\hline & \multicolumn{2}{|c|}{$\begin{array}{l}\text { Diffusion of other BIM type of education and } \\
\text { activities for knowledge boosting and acquisition } \\
\text { of transferable skills through workshops, } \\
\text { conferences, seminars, etc. }\end{array}$} & $\begin{array}{l}\text { - Academics } \\
\text { - BIM education providers } \\
\text { - Industry } \\
\text { - Government }\end{array}$ & \\
\hline & \multicolumn{2}{|c|}{$\begin{array}{l}\text { Establishment of minimum knowledge } \\
\text { requirements to undertake higher education } \\
\text { degrees such as masters and research. That is to } \\
\text { avoid teaching new things to students that have } \\
\text { some gaps in knowledge. }\end{array}$} & $\begin{array}{l}\text { - Academics } \\
\text { - Industry: to identify problems } \\
\text { in practice and propose research } \\
\text { in the field }\end{array}$ & \\
\hline \multicolumn{5}{|c|}{ Industry } \\
\hline \multirow[t]{2}{*}{ Strategy stage } & \multicolumn{3}{|c|}{ Implementation stage } & Revision stage \\
\hline & & Actions & Participants involved & $\bullet$ \\
\hline \multirow{4}{*}{$\begin{array}{l}\text { - Designation of a BIM } \\
\text { Champion to lead the } \\
\text { strategy } \\
\text { - Identification of } \\
\text { the BIM scope of the } \\
\text { company } \\
\text { - Identification of } \\
\text { the BIM abilities } \\
\text { required per role in the } \\
\text { organisation } \\
\text { - Identification of the } \\
\text { training to be taken by } \\
\text { the staff depending on } \\
\text { their role in the team and } \\
\text { requirements of the type } \\
\text { of projects: } \\
\text { - Managerial levels; } \\
\text { - Remainder staff; } \\
\text { - The client, when } \\
\text { needed }\end{array}$} & \multirow[t]{3}{*}{$\begin{array}{l}\text { BIM Education } \\
\text { for the staff }\end{array}$} & $\begin{array}{l}\text { Higher education: Large } \\
\text { funding needed. Suitable } \\
\text { for large companies with } \\
\text { considerable budget } \\
\text { dedicated to training }\end{array}$ & $\begin{array}{l}\text { Provided by: } \\
\text { - Academia }\end{array}$ & \multirow[t]{4}{*}{$\begin{array}{l}\text { - Evaluation of the } \\
\text { performance of the staff and } \\
\text { the client } \\
\text { - Comparisons of project } \\
\text { outcomes and performances } \\
\text { before and after the strategy. }\end{array}$} \\
\hline & & $\begin{array}{l}\text { Acquisition/upskill of } \\
\text { software abilities: }\end{array}$ & $\begin{array}{l}\text { Provided by: } \\
\text { - Software developers; } \\
\text { - Expert(s) hired by the } \\
\text { organisation } \\
\text { - Skilled staff from the } \\
\text { company designated by the BIM } \\
\text { champion. }\end{array}$ & \\
\hline & & $\begin{array}{l}\text { Acquisition of different } \\
\text { transferable skills: } \\
\text { - CPD programs } \\
\text { - Attend to workshops, } \\
\text { conferences, } \\
\text { seminars, etc. }\end{array}$ & $\begin{array}{l}\text { Provided by: } \\
\text { - Organisation } \\
\text { - BIM education providers }\end{array}$ & \\
\hline & $\begin{array}{l}\text { BIM education } \\
\text { to the client }\end{array}$ & $\begin{array}{l}\text { To receive consultancy in the } \\
\text { following areas: } \\
\text { - Introduction to BIM } \\
\text { - Establishment of BIM goals } \\
\text { for the project } \\
\text { - Documentation } \\
\text { management }\end{array}$ & $\begin{array}{l}\text { BIM consultant from: } \\
\text { - The organisation } \\
\text { - An independent BIM } \\
\text { consultant }\end{array}$ & \\
\hline
\end{tabular}


and programs provided helped them to get the knowledge they were seeking. According to Byrne (2015), this initiative is being implemented in the UK where universities are being examined by undergraduate students about the BIM content of the programs. Moreover, academics can evaluate, through the performance of the students, if the programs' content, teaching techniques, and BIM learning materials were enough to "BIM educate" them effectively. This evaluation can also help them to see if they need to be more prepared academically to offer an education of better quality to the students and cover any gap in the knowledge they might have. If the implementation of knowledge transfer partnerships, internships and co-ops are possible, feedback from industry is highly valuable as well. Through the evaluation of the "interns", they can identify any deficiency that can be corrected by improving the BIM curricula or the teaching techniques implemented. It is important to point out that after the stage of revision is recommended to seek for accreditation of the programs created. That will give more trust to BIM learners when looking for BIM education programs and will help in their diffusion. In the industry, this revision stage can be executed by evaluating the performance of the personnel and the client and making comparisons of the outcomes of projects before and after the provision of BIM education.

\section{CONCLUSION}

The proposed conceptual BIM education framework of this study is part of the research "Decision support toolkit to implement BIM in the Dominican Republic". The necessity of such framework was identified in the literature review and a preliminary study conducted for the research. The framework was developed by examining the literature about BIM education and analysing existing BIM education frameworks of this nature worldwide.

The proposed conceptual framework intended to be more complete than the group of frameworks analysed regarding strategies. It has an ample scope regarding whom the delivery of education is directed to: higher education students, current professionals, and clients. The framework establishes three stages to planning the delivery of BIM education in Academia and the industry. Suggestions from the literature review and the frameworks analysed were considered for the development of the framework. That is the reason why, in some parts, the proposed framework has similarities with these frameworks. For the Academia section, the framework followed several strategic suggestions from the EWG framework. That can be seen in the actions of the strategy stage and some actions of the implementation stage. The proposed framework also took the collaborative essence from the EWG framework. The collaboration between Academia and the industry is proposed in the literature review for the enhancement of BIM education, but seeing this collaboration in the EWG framework helped significantly in the development of the proposed framework. Similar to the EWG, the LOF framework considers Academia and the industry but does not have similarities with the proposed framework as it presents learning outcomes and is based on a government strategy. It could be noted that the insertion of learning outcomes is beneficial as they help to assure that the learners will acquire the knowledge they are demanded by the industry. However, the proposed framework did not consider their inclusion as its aim was the development of strategies for the delivery of BIM education; and it was also too early to take learning outcomes into consideration for this country. In the industry section, the proposed framework has similarities to Kumar's framework and roadmap. Important actions suggested by Kumar were followed, especially in the strategy and revision stage.

Further data collection is pending to be executed in the country, which could suggest enhancements in the framework. 


\section{REFERENCES}

Adamu, Z. A. (2016). How universities are teaching BIM: A review and case study from the UK. Journal of Information Technology in Construction, 21(8), 119-139.

AIA-CA. (2012). BIM education, BIM in practice, a Position Paper by the Australian Institute of Architects and Consult Australia'. Retrieved June 14, 2016, from https://www.Academia.edu/1915059/BIM_Education_ BIM_in_Practice_11_co-authors_

Al Ahbabi, M., \& Alshawi, M. (2015). BIM for client organisations: A continuous improvement approach. Construction Innovation, 15(4), 402-408. doi:10.1108/CI-04-2015-0023

Alshenqeeti, H. (2014). Interviewing as a data collection method: A critical review. English Linguistics Research, 3(1), 39. doi:10.5430/elr.v3n1p39

Arayici, Y., Coates, P., Koskela, L., Kagioglou, M., Usher, C., \& O'reilly, K. (2011). Technology adoption in the BIM implementation for lean architectural practice. Automation in Construction, 20(2), 189-195. doi:10.1016/j. autcon.2010.09.016

Atkinson, R., \& Flint, J. (2001). Accessing hidden and hard-to-reach populations: Snowball research strategies. Social Research Update, 33(1), 1-4.

Australian Construction Industry Forum \& Australasian Procurement and Construction Council. (2014). A framework for the adoption of project team integration and building information modelling. Strategic Forum for the Australasian Building and Construction Industry. Retrieved June 4, 2016, from http://www.apcc.gov. au/ALLAPCC/Framework_WEB.pdf

Becerik-Gerber, B., Gerber, D. J., \& Ku, K. (2011). The pace of technological innovation in architecture, engineering, and construction education: Integrating recent trends into the curricula. Journal of Information Technology in Construction, 16, 411-432.

BIM Task Group. (2012). The BIM Task group publishes the initial BIM learning outcomes framework. Retrieved June 1, 2016, from www.bimtaskgroup.org

Byrne, C. (2015). Building information modelling in Australia, lessons from the UK. International Specialised Skills Institute. Retrieved October 20, 2016, from http://www.issinstitute.org.au/wp-content/media/2015/05/ Report-Byrne-FINAL-LowRes.pdf

Computer Integrated Construction Research Program. (2013, June). BIM planning guide for facility owners. version 2.0. The Pennsylvania State University. Retrieved June 10, 2016. from http://bim.psu.edu/resources/ owner/bim_planning_guide_for_facility_owners-version_2.0.pdf

Crabtree, B. F., \& Miller, W. L. (1999). Doing qualitative research. In Annual North American Primary Care Research Group Meeting, 19th, May 1989, Quebec, PQ, Canada. Sage Publications, Inc.

Designing Buildings. (2016). Employer's BIM advise. Designing Buildings Wiki. Retrieved June 10, 2016, from https://www.designingbuildings.co.uk/wiki/Employer\%27s_BIM_adviser

Eadie, R., Browne, M., Odeyinka, H., McKeown, C., \& McNiff, S. (2013). BIM implementation throughout the UK construction project lifecycle: An analysis. Automation in Construction, 36, 145-151. doi:10.1016/j. autcon.2013.09.001

Garavan, T. N. (1997). Training, development, education and learning: Different or the same? Journal of European Industrial Training, 21(2), 39-50. doi:10.1108/03090599710161711

Gardner, J. C., Hosseini, M. R., Rameezdeen, R., \& Chileshe, N. (2014). Building information modelling (BIM) education in South Australia: Industry needs. In Proceedings of the 5th International Conference on Engineering, Project, and Production Management (EPPM 2014) (pp. 293-302).

Hardin, B., \& McCool, D. (2015). BIM and Construction Management: Proven Tools, methods, and workflows. John Wiley \& Sons.

Hogle, L. (2013). Industry + Academia: The perfect partnership. Paper presented at the BIM Academic Education Symposium. Setting the Course for a BIM Educational Strategy, Washington, D.C. 
Kocaturk, T., \& Kiviniemi, A. (2013). Challenges of integrating BIM in architectural education. Paper presented at the eCAADe 2013: Computation and Performance, Delft, the Netherlands.

Kugbeadjor, W., Suresh, S., \& Renukappa, S. (2015). BIM awareness and readiness of postgraduate built environment students in West Midlands universities, UK. In CIB International Conference Proceedings. Going North for Sustainability: Leveraging Knowledge and Innovation for Sustainable Construction and Development (pp. 531-543). London: IBEA Publications.

Kumar, B. (2015). A practical guide to adopting BIM in construction projects. Dunbeath: Whittles Publishing.

Lee, N., \& Hollar, D. A. (2013). Probing BIM education in construction engineering and management programs using industry perceptions. Paper presented at the 49th ASC Annual Int. Conf. Proc., California Polytechnic State Univ., San Luis Obispo, CA.

BIM Level 2. (2016). BIM learning outcomes framework. BIM Level 2. Retrieved June 3, 2016, from http:// bim-level2.org/globalassets/pdfs/learning-outcomes-framework.pdf

Macdonald, J., \& Granroth, M. (2013). Multidisciplinary AEC education utilising BIM/PLIM tools and processes. In Proceedings of the 10th Product Lifecycle Management for Society (PLM) (pp. 663-674). Springer.

Macdonald, J. A. (2012). A framework for collaborative BIM education across the AEC disciplines. Paper presented at the 37th Annual Conference of Australasian University Building Educators Association (AUBEA), New South Wales, Sydney.

Macdonald, J. A., \& Mills, J. E. (2011). The potential of BIM to facilitate collaborative AEC education. Paper presented at the American Society for Engineering Education, Washington, D.C.

Mack, N., Woodsong, C., MacQueen, K. M., Guest, G., \& Namey, E. (2005). Qualitative research methods: A data collector's field guide. North Carolina: FHI.

Maghiar, M. (2016). Knowledge transfer into a BIM course through technology-driven solutions for real-world construction projects. Paper presented at 10th BIM Academic Symposium \& Job Task Analysis Review, Orlando Florida.

Magiera, J. (2013). Integrated teaching for integrated engineering practice-BIM on campus. Paper presented at $210^{\text {th }}$ International Conference on Computer Methods in Mechanics, Poznan, Poland.

Masadeh, M. (2012). Training, education, development and learning: What is the difference? European Scientific Journal, 8(10), 62-68.

McGraw-Hill Construction. (2014). The business value of BIM owners. Retrieved June 14, 2016, from http:// i2sl.org/elibrary/documents/Business_Value_of_BIM_for_Owners_SMR_(2014).pdf

Miller, G., Sharma, S., Donald, C., \& Amor, R. (2013). Developing a building information modelling educational framework for the tertiary sector in New Zealand. Paper presented at the IFIP International Conference on Product Lifecycle Management (pp. 606-618). Springer, Berlin, Heidelberg. doi:10.1007/978-3-642-41501-2_60

Oladosu, A. (2009). Concepts in education. fundamental principles and practice of instruction. Ilorin. University of Ilorin.

Peters, R. S. (Ed.). (2010) The concept of Education New York: Routledge.

Rooney, K. (2017). BIM education - global. 2017 update report. ICIS Integrated Construction. Retrieved May 28, 2017, from http://www.canbim.com/single-post/2017/05/29/NATSPEC-Global-BIM-Education-Report-2017

Sabongi, F. J. (2009). The integration of BIM in the undergraduate curriculum: An analysis of undergraduate courses. Paper presented at the International Proceedings of the 45th ASC (Associated Schools of Construction) Annual Conference, Gainesville, Florida.

Sanchez, A. X., Kraatz, J. A., \& Hampson, K. D. (2014). Towards a national strategy. Research report 1. Sustainable Built Environment National Research Centre. Retrieved October 20, 2016, from http://www.sbenrc. com.au/wp-content/uploads/2013/10/National-Strategy-research-report-FINAL.pdf

Sharp, J. (2015). Clients need to be educated on BIM. BIM Plus. Retrieved June 6, 2016, from http://www. bimplus.co.uk/people/clients-need-be-educated-bim/ 
Succar, B., \& Sher, W. (2014). A competency knowledge-base for BIM learning. Australasian Journal of Construction Economics and Building-Conference Series, 2(2), 1-10. doi:10.5130/ajceb-cs.v2i2.3883

Suwal, S., Jäväjä, P., Rahman, M. A., \& Gonzalez, V. (2013). Exploring BIM-based education perspectives. Paper presented at 38th Australasian Universities Building Education Association Conference, Auckland, New Zealand.

Tran, A., Mills, J., Morris, D., \& Phillips, M. (2012). "All hands on deck": Collaborative Building Design Education for Architects and Engineers. Paper presented at International Conference on Innovation, Practice and Research in Engineering Education (EE2012), Coventry University, Coventry.

Underwood, J., Ayoade, O., Khosrowshahi, F., Greenwood, D., Pittard, S., \& Garvey, R. (2015). Current position and associated challenges of BIM education in UK higher education. BIM Academic Forum. Retrieved October 2, 2016, from http://buildingsmart.pl/baf_bim_education_report_2015.pdf

Underwood, J., Khosrowshahi, F., Pittard, S., Greenwood, D., \& Platts, T. (2013). Embedding building information modelling (BIM) within the taught curriculum: Supporting BIM implementation and adoption through the development of learning outcomes within the UK academic context for built environment programmes. BIM Task Group. Retrieved October 2, 2016, from http://www.bimtaskgroup.org/wp-content/uploads/2013/10/ BIM_June2013.pdf

Wong, K., Wong, F. K., \& Nadeem, A. (2011). Building information modelling for tertiary construction education in Hong Kong. Journal of Information Technology in Construction, 16, 467-476.

Wu, W., \& Issa, R. R. (2013). BIM education for new career options: An initial investigation. Paper presented at the BIM Academic Workshop, Washington, D.C. 
Ana Karina Silverio Rodriguez is a Dominican Architect graduated Cum Laude in 2011 at UASD (Universidad Autonoma de Santo Domingo). She continued her studies in the United Kingdom 2 years later by undertaking a MSc in Building Information Modelling at the University of Wolverhampton, graduating with Merit. She is currently doing a PhD in Built Environment under the title "Decision support toolkit to implement BIM in the Dominican Republic" at the same university for the period 2015-2019. Her professional experience started in her home country by working in the Town Planning Department of the Santo Domingo Este City Council for 3 years. She also worked as an independent architect during this period. In the process of the PhD she has been involved in research, publication of papers and have acquired professional experience. She was part in the research of the University of Wolverhampton "Investigating the Health and Safety Knowledge of North Indian Migrants Working in the West Midlands Construction Industry" in July 2015, along with Raymond Olayinka and Sukhtaj Singh, supervised by her Director of Studies Dr. Subashini Suresh. She also published in November 2015 a Conference paper with the title: "Challenges of BIM Implementation in Sustainable Residential Projects in the UK and Future Perspective" for the Conference "Going North for Sustainability" in London, UK, supervised by her supervisory team: Dr. Subashini Suresh (Director of Studies) and Dr. David Heesom and Dr. Renukappa Suresh (supervisors). She also published the conference paper "BIM education framework for clients and professionals of the construction industry" for the "1st International UK BIM Academic Forum Conference" in Glasgow in September 2016, under the supervision of her supervisory team for the PhD. She has also acquired professional experience in the field of BIM by doing a six-month internship in the company Tweedale, located in Wolverhampton.

Subashini Suresh has over 19 years of experience in research, teaching and practice in the area of Project Management and has worked in the area of Architecture, Engineering and Construction (AEC) sector. Currently, she is a Reader of Construction Project Management at the School of Architecture and Built Environment, University of Wolverhampton. She holds a PhD in knowledge management. She received Rewarding Excellence Award for Innovation in Teaching and also for Blended Learning Tutor. She is a Fellow of the Higher Education Academy (FHEA) and Fellow of Royal Society for the encouragement of Arts, Manufactures and Commerce (FRSA). She has published over 150 academic publications, which include 32 journal papers, 96 conference papers, four articles, eight book chapters, 15 reports and three books. In the last three years, she was involved in Marie Curie Project and ERDF Project. In the EU FP7 Marie Curie IAPP (Industry and Academia Partnerships and Pathways), total cost is $£ 850,000$ (approx. €1 million), 2013 to 2017. The project was the winner of 2017 Innovation Award under the Built Environment Construction Excellence Awards in UK. Her key areas of interest are as follows: construction project management, knowledge management, building information modelling, health and safety, sustainability/ green construction, emerging technologies, quality management, leadership in change management initiatives, organisational competitiveness, business process improvement, lean construction, risk management and Six Sigma leadership.

Dr. David Heesom holds a BEng (Hons) degree in Civil Engineering from Loughborough University and an MSc (distinction) in CAD for Construction from the University of Wolverhampton. He completed his PhD at the University of Wolverhampton in 2004, which developed a suite of software tools to allow more effective planning on construction sites by utilising real time ' $4 D$ ' BIM techniques. He is Chartered member of the Chartered Institute of Architectural Technologists (CIAT) and a Member of the Institute of Knowledge Transfer. His professional experience as an infrastructure engineer working with Atkins involved various projects including a large infrastructure project in Dublin, Ireland and the 3D computer-modelling for a large project in the North of England. David joined the University of Wolverhampton as a Research Fellow undertaking a collaborative EPSRC funded project entitled 'The Virtual Construction Site' with University College London, UMIST, Carillion, AMEC, Atkins and Teesside University. Since then his research and teaching have focused on the areas of Building Information Modelling, VR and AR for the built environment, HD laser scanning, the Internet of Things and 4D/5D modelling for construction management. He has published this work widely and has been responsible for delivering over $£ 2.5 \mathrm{~m}$ worth of R\&D projects. This has included successfully operated numerous Knowledge Transfer Partnerships (KTP) with each of these achieving high grades following independent assessment. The most recently completed KTP focused on the implementation of BIM and $3 D$ technologies for the nuclear ventilation sector was awarded an 'A-Grade (Outstanding) by an independent review. His expertise in the field of BIM led to collaboration with CITB, which saw him deliver over 25 seminars throughout the UK for various industry bodies and construction companies on the impact of BIM on the construction industry. In 2014, he was awarded the prestigious Industrial Secondment Grant from the Royal Academy of Engineering to spend time back in the industry implementing serious games approaches with BIM data for construction training. David has presented work and run workshops in the field of BIM and 3D technologies at various international events including Germany, Eire, Ukraine, Canada, China, Egypt, USA and Canada. 
Suresh Renukappa currently serves as a Senior Lecturer in the Faculty of Science and Engineering at the University of Wolverhampton. He holds a PhD in managing change and knowledge associated with sustainability initiatives for improved competitiveness. He has over 20 years of research, consultancy, project management and teaching experience in a wide range of business and management areas across industrial sectors in both developed and emerging economies. His research interests cover, but not limited to, sustainability strategies for competitive advantage; carbon reduction strategies; corporate social responsibility; smart cities development; leading change towards sustainability; knowledge management; public-private partnerships; cloud computing; infrastructure asset management; and sustainable infrastructure investment and development. He has successfully executed more than 30 large projects and authored over 80 papers which have been published in journals, book chapters and conference proceedings. 